\title{
Towards an understanding of dynamic demand on ground support
}

\author{
Y. Potvin Australian Centre for Geomechanics, The University of Western Australia, Australia
}

J. Wesseloo Australian Centre for Geomechanics, The University of Western Australia, Australia

\begin{abstract}
The proper understanding of the functioning of ground support under dynamic loading and the current approaches to designing of dynamic support is plagued by a great deal of uncertainty and lack of knowledge. This applies equally to the understanding of the support capacity as well as the demand placed on to the support due to dynamic loading. Stacey (2012) suggests that the lack of understanding currently leads to a case of design indeterminacy. This paper does not aim to solve this problem of design indeterminacy but to explore some of the issues that need considerations to better understand the dynamic demand on ground support systems.
\end{abstract}

\section{$1 \quad$ Background}

The hazard associated with mine seismicity generally increases with stress which in turn increases with depth. As the mining industry is becoming more mature, orebodies are mined at increasing depth. In South Africa, the deepest mines have already reached beyond $4 \mathrm{~km}$, in Canada $3 \mathrm{~km}$ and in Australia, where the horizontal stress gradient is relatively high, underground mining has progressed beyond $2 \mathrm{~km}$. Deeper mining means that in general, there will be more frequent occurrence of large seismic events and elevated seismic hazard.

The damage caused by a seismic event is commonly called a rockburst. There is a great deal of uncertainty and variability associated with the spatial and temporal occurrence of seismicity. On top of that, the interaction of the ground motion with the excavation and the installed ground support is extremely complex and is currently not well understood. Apart from the possibility of fatality, economic consequences may also be severe. In Australia for example, the last two fatalities related to rockburst (Beaconsfield in 2006 and Big Bell in 2000) have resulted in mines shutting down for periods exceeding well over one year.

The uncertainty combined with the potentially severe consequences lead to a generally high risk associated with rockbursting.

Fortunately, only a relatively small proportion of all seismic events cause damage. The main factors determining the rockburst damage level include the magnitude of the seismic event and its proximity to excavations. The larger and the closer the seismic event is to an excavation, the more likely it is to experience damage. Other factors also influence the severity of damage, including the localised ground conditions and the stress field around the nearby excavations and the capability of the ground support system to sustain dynamic loading (Heal, 2010), the source mechanism of the event and the relative orientation of rock mass deformation and the excavation.

To mitigate rockburst risks, a combination of a strategic approach based on optimising the mining sequence to minimise stress build-up on seismically active structures and a tactical approach relying on dynamically capable ground support is often implemented (Potvin, 2009). However, the engineering design of dynamically capable ground support systems suffers from major gaps in the current technology.

These gaps exists both in assessing the capacity of the support system and in estimating the dynamic demand. Although a brief discussion on the capacity is made, the paper focuses on the demand estimate. The object of the current paper is to explore some of the issues that need considerations to better understand the dynamic demand on ground support systems. 


\section{$2 \quad$ Support capacity}

Ground support design must rely on the assessment of both the demand and capacity of the support system. Significant research work has been conducted over the last two decades to better understand the dynamic capacity of ground support (Yi and Kaiser, 1994; Kaiser et al., 1996; Ortlepp and Stacey, 1997, 1998; Ortlepp et al., 1999; Stacey and Ortlepp, 1999; Ortlepp and Swart, 2002; Gaudreau et al., 2004; Plouffe et al., 2008; Player et al., 2004, 2008a, 2008b, 2009; Villaescusa et al., 2005; Tannant et al., 1993, 1994; Hagan et al., 2001; Hildyard and Milev, 2001; Reddy and Spottiswoode, 2001; Espley et al., 2002; Archibald et al., 2003; Heal et al., 2005; Andrieux et al., 2005; Heal and Potvin, 2007; Potvin and Wesseloo, 2010). In this work, the dynamic load applied to reproduce rockburst loading involved either some form of drop tests or blasting tests.

Stacey (2012) rightly argued that neither of these is "truly representative of rockburst loading, in a similitude sense". These tests by no means account for the complexity of the loading transmitted from the failing rock to the support elements which likely involves a combination of several mechanisms including tensile, shear, bending and torsion. It should be noted, however, that this was in many cases not the intention of the tests. These tests aim to subject ground support elements to sudden impulse loading to enable a quantification of its performance under dynamic loading. These tests should, therefore, be seen as index tests and the absolute values of, for example, energy absorption, should be used with caution.

Furthermore, the drop testing programmes to date have generally only looked at ground support elements individually, with no means to account for the load transfer or cumulative energy absorption.

Stacey (2012) makes the point that although the results from testing individual elements do not provide useful data for deterministic support design purposes, they provide essential information to understand the behaviour and compare the capacity of support elements under tensile dynamic load.

Recent research work on improving our understanding of the dynamic demand on ground support systems is almost non-existent. Therefore, since the capacity of ground support systems and the demand from seismically induced dynamic loading cannot be quantified reliably, Stacey (2012) concludes that "a clear case of design indeterminacy results".

This design indeterminacy can only be solved with the development of methods to quantify the true system capacity. In this regard the combined use of instrumented laboratory tests and detailed numerical modelling will prove valuable.

\section{Challenges in understanding the dynamic demand on ground support systems}

There are many challenges in trying to assess the true dynamic demand on ground support systems encompassing every aspect of the problem from source to effect. These include the complexities of the radiation, refraction and reflection of the seismic waves, its interaction with excavations and the mechanism by which it loads the support.

Seismic events produce dynamic stress waves which, based on the principles of physics, attenuate as they radiate from the source through the rock mass. Given that rock masses are complex and imperfect composite media, and most mines have complicated geometries, the wave propagation/attenuation effects from any seismic event can be extremely complex and difficult to model or effectively account for in design.

In particular, the effect of rock mass anisotropy on the seismic wave radiation pattern can be significant as reported by Hildyard (2007). Depending on the stress field, the stiffness of the rock layers and the presence of infill material between layers, the attenuation across lamination can be much more pronounced than along lamination. This is indeed difficult to take into account when estimating the attenuation of the stress wave as a function of the distance from the source, as the waves often travel through different rock mass domains with different degrees of lamination. 


\subsection{Radiation pattern}

For simplicity's sake the radiation pattern from a seismic event is often ignored in rock engineering evaluation and both the P-wave and S-wave intensity is assumed to be constant in all directions from the source. This is a simplification of a much more complex behaviour described by Aki and Richards (1980).

Figure 1(a) shows the radiation pattern of the S-wave and P-wave displacement in a plane of constant azimuth generated by a double-couple point source. Figure 1(b) illustrates the same concept in a different way, where the thickness of the line denotes the wave intensity as it would radiate outward from its source in a circular (spherical in 3D) manner.

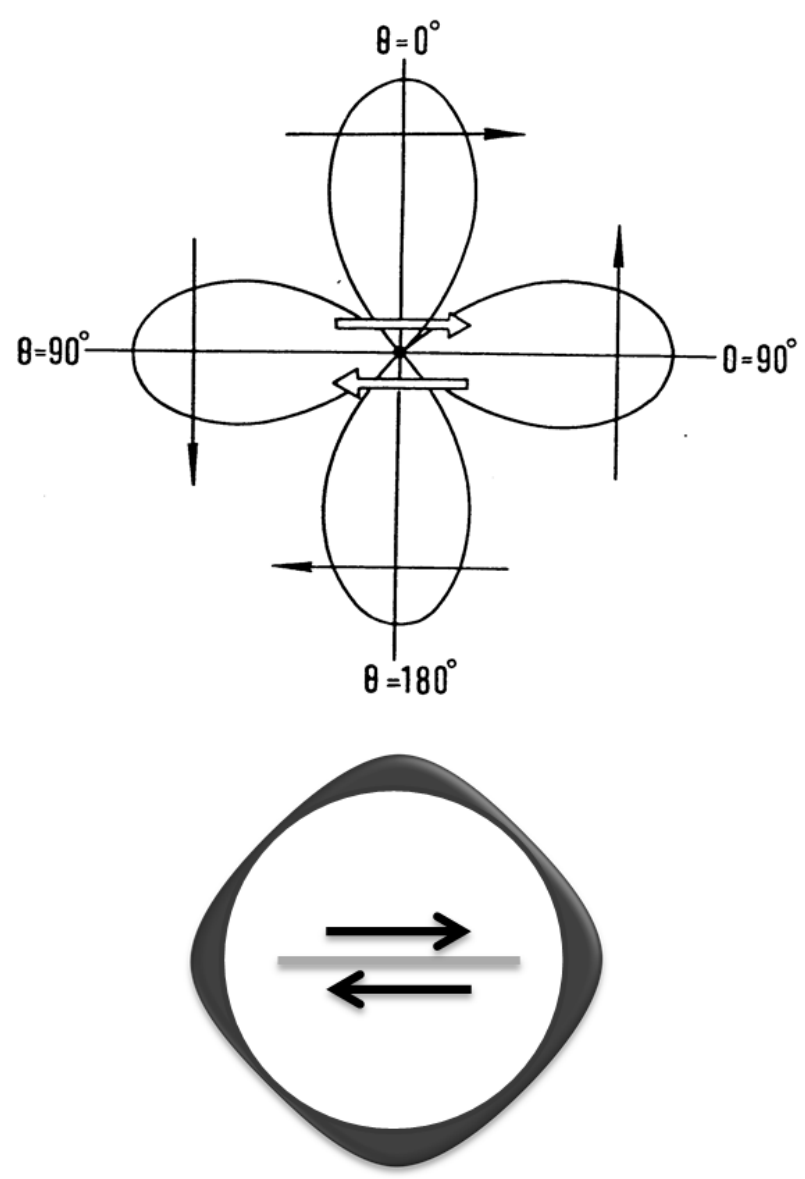

S-wave

a)

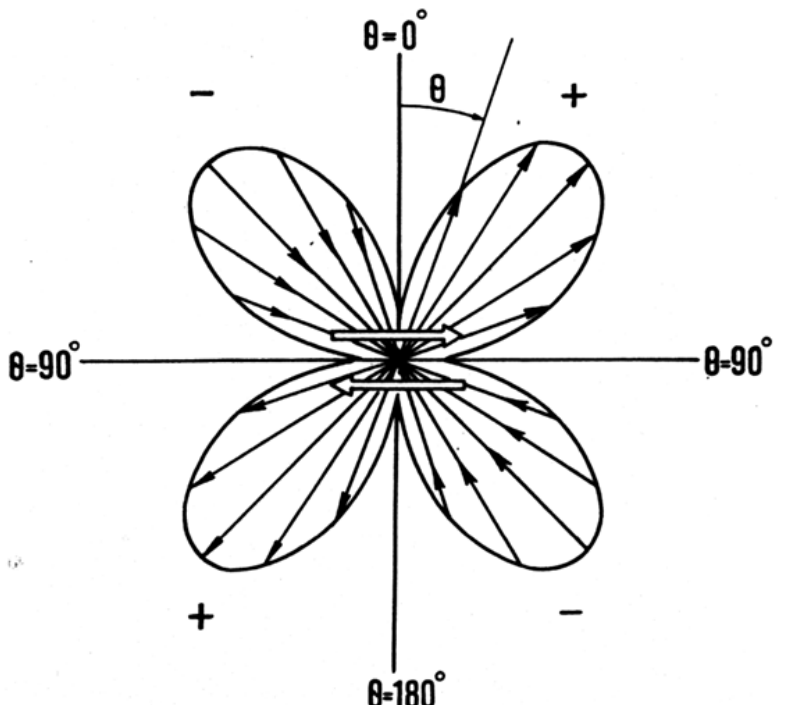

$\theta=180^{\circ}$

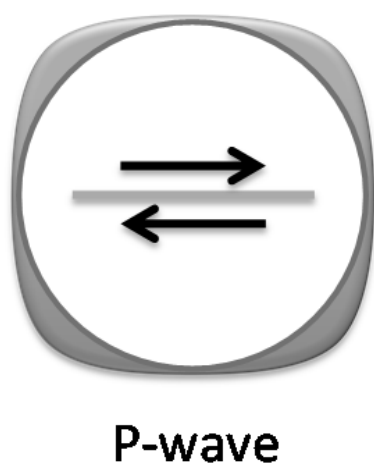

b)

Figure 1 Illustration of the radiation pattern in two dimensions (original line drawing after Aki and Richards, 1980)

Figure 2 illustrates the importance of a due consideration of the radiation pattern in post mortem analysis and design. These charts show a theoretical S-wave ppv, calculated on different points in a mine following a seismic event. Both the colour and size of the points along the mine excavations are scaled according to the theoretical ppv. The difference in Figure 2(a) and (b) is a result only of a different slip orientation. Figure 2(c) assumes a spherical radiation pattern. Note that these figures only illustrate the influence of the radiation pattern. The effect of geological features, lithology and mining voids on the radiating waves is not taken into account and is discussed in the following section. 


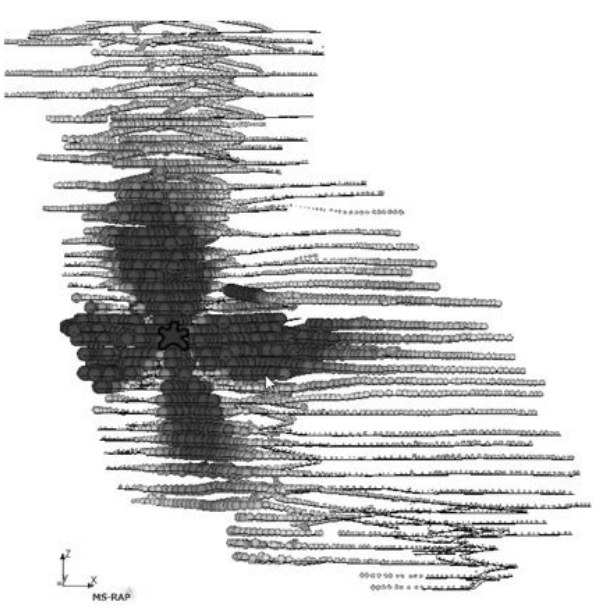

a)

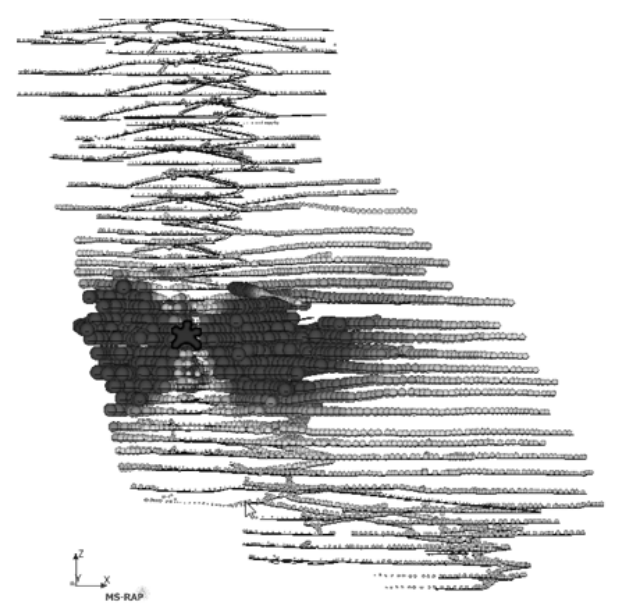

b)

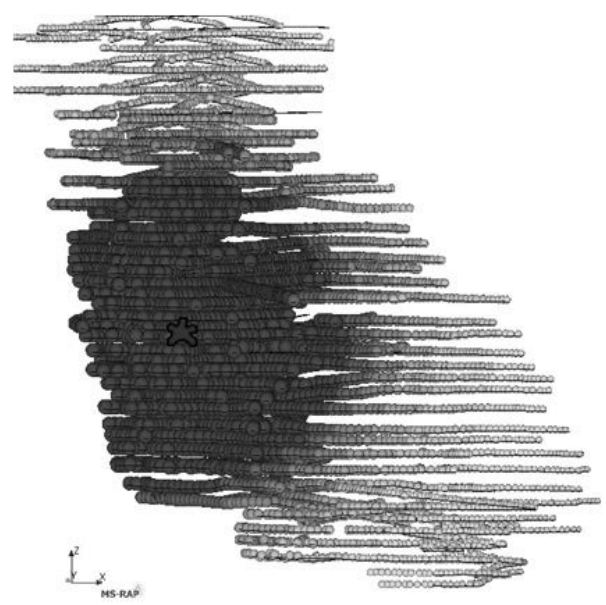

c)

Figure 2 Illustration of the influence of the radiation pattern on the wave intensity in three dimensions; a) and b) theoretical S-wave ppv resulting from a large seismic event. The difference in the two illustrations is a result of the different assumed slip direction only; $c$ ) theoretical S-wave ppv resulting from a large seismic event assuming a spherical radiation patterns

\subsection{Reflection and refraction of the stress wave}

The presence of mine openings, major discontinuities and lithological contacts and different lithological units will create both reflection and refraction as the stress waves radiate from the source. Daehnke (1997) used a very simple photo-elastic physical model to demonstrate the complexity of stress waves reflection and refraction when interacting with one long and narrow excavation, akin to a longwall front (Figure 3(a)). $\mathrm{He}$ also demonstrated that the presence of discontinuity planes creates further reflection and refraction of the waves (Figure 3(b)). 


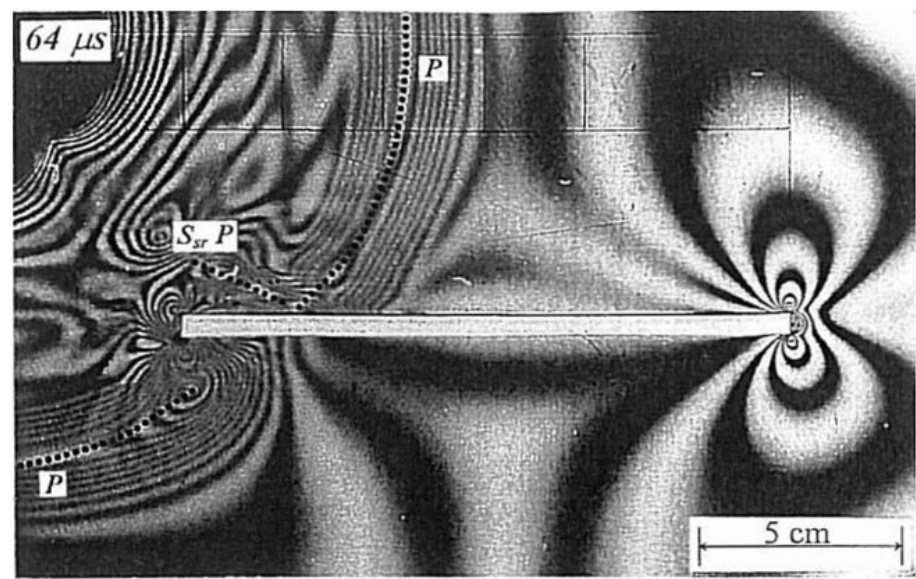

a)

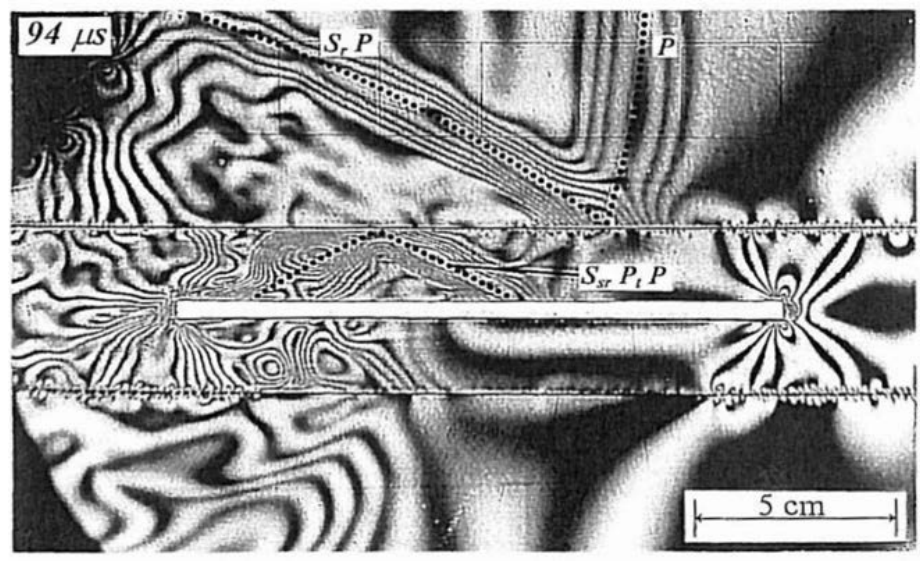

b)

Figure 3 Photoelastic model showing the reflection and refraction of stress wave when; a) interacting with a long narrow opening; and b) when interacting with a similar opening bounded by two discontinuity planes above and under the opening (after Daehnke, 1997)

If one looks at the complexity of the geometry of a mature mine layout combined with its geological settings, which often includes multiple fault systems and lithological contacts, the difficulties related to simulating the reflection/refraction patterns of real seismic waves in a mining environment become selfevident.

One possible effect of this complex reflection/refraction phenomenon is the potential superposition of stress waves to create locally a very high dynamic loading condition. This could contribute (amongst other factors) to a very high localised load resulting in the occurrence of isolated rockburst damage, often observed in underground mines (Figure 4) following a far field seismic event. 


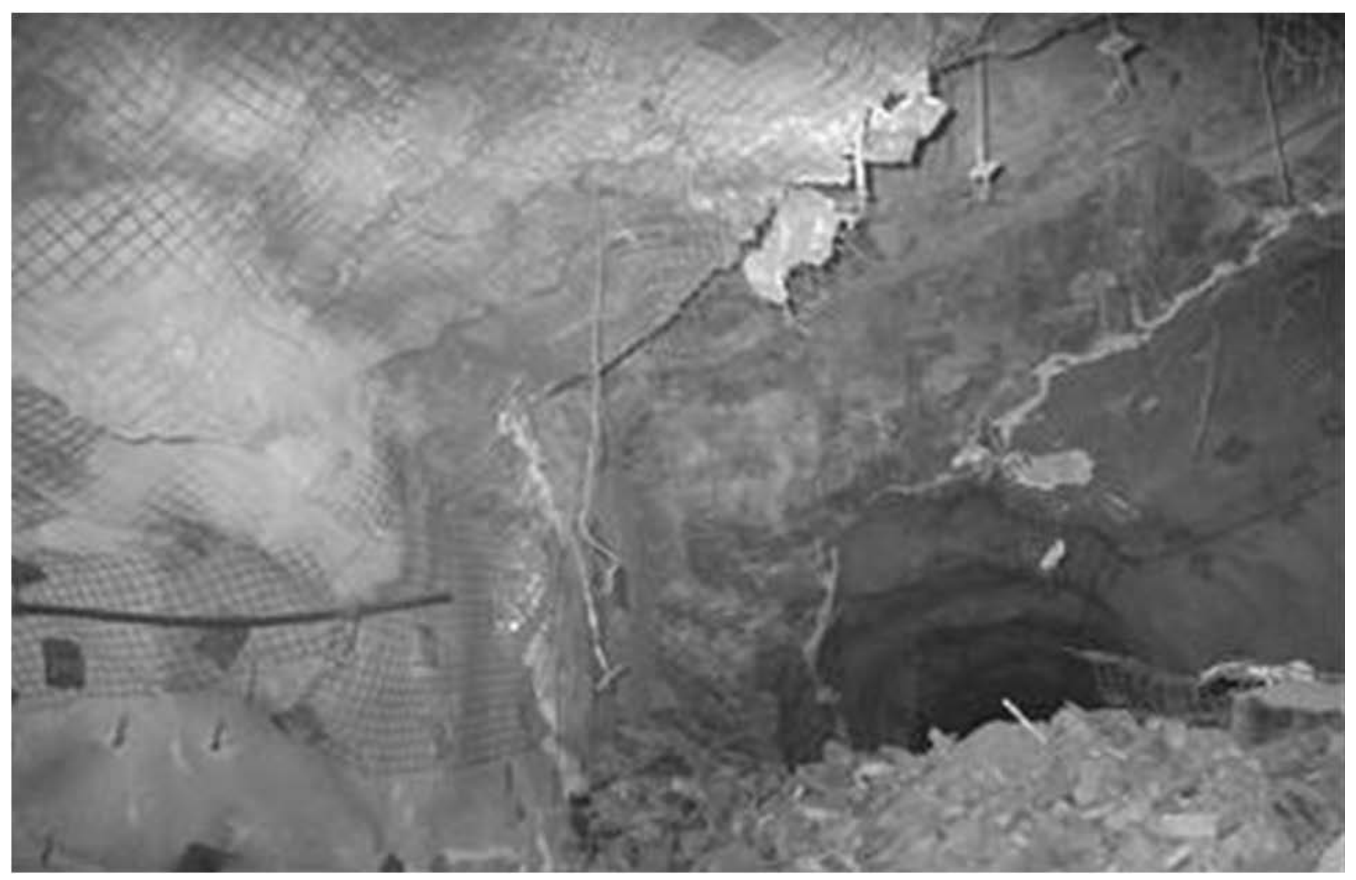

Figure 4 Photograph of a localised incidence of seismically induced damage. It is noted that the surrounding support to the damage area is showing no signs of loading

\subsection{The scale-distance relationship and the dynamic demand expressed as ppv}

In many cases, rockburst damage occurs at several locations and different distances from the theoretical hypocentre of a large event. Due to the radiation and attenuation, the intensity of the seismic wave reduces exponentially with distance from the source. To capture this effect into a single parameter for design purposes, traditionally the peak particle velocity (ppv) is used in mining while peak particle acceleration (ppa) is also used in other branches of earthquake engineering (St John and Zahrah, 1987).

Some have argued that ppa should be used as this can be related to a force through the simple principle of Newtonian physics by multiplying the acceleration with a mass of ejection. This argument, however, ignores the complex wave-rock mass-excavation interaction. Kaiser and Maloney (1997) points out that only low frequency accelerations, with wave lengths sufficiently long to accelerate the entire volume of rock in one direction, are relevant for damage prediction and support design.

St John and Zahrah (1987) argue that peak ground acceleration is not necessarily a good measure of damage potential because it is often repetitive shaking with strong energy content that leads to permanent deformation and damage. As a result ppa has been used to refer to an acceleration which is less than the peak value but is more representative of the damage potential (Newmark and Hall, 1982).

McGarr (1983) showed that experienced damage better correlated with ppv than with ppa and Kaiser et al. (1996) mention that:

\section{"...the ground motion velocity represented by the peak particle velocity ppv is accepted as the most representative parameter to define the dynamic design load".}

Design methodology often used in mining assesses the energy balance (energy demand versus capacity of energy absorption) where to assess the demand, the kinetic energy of a mass moving at a given velocity as a result of a seismic event can be determined. An underlying assumption here is that the movement can be characterised by ppv and takes its origin in the stress (or strain) waves generated by a seismic event.

Having said this, it is fair to question whether ppv is the ideal parameter to assess the demand on ground support and wether the way it is generally applied and assessed is adequate. 
Generalised ground motion relationships have been developed to capture the effect of attenuation in the ground motion with distance from the source. The most used relationship is that presented by Kaiser et al. (1996) and Kaiser and Maloney (1997) which is often represented in chart form as shown in Figure 5.

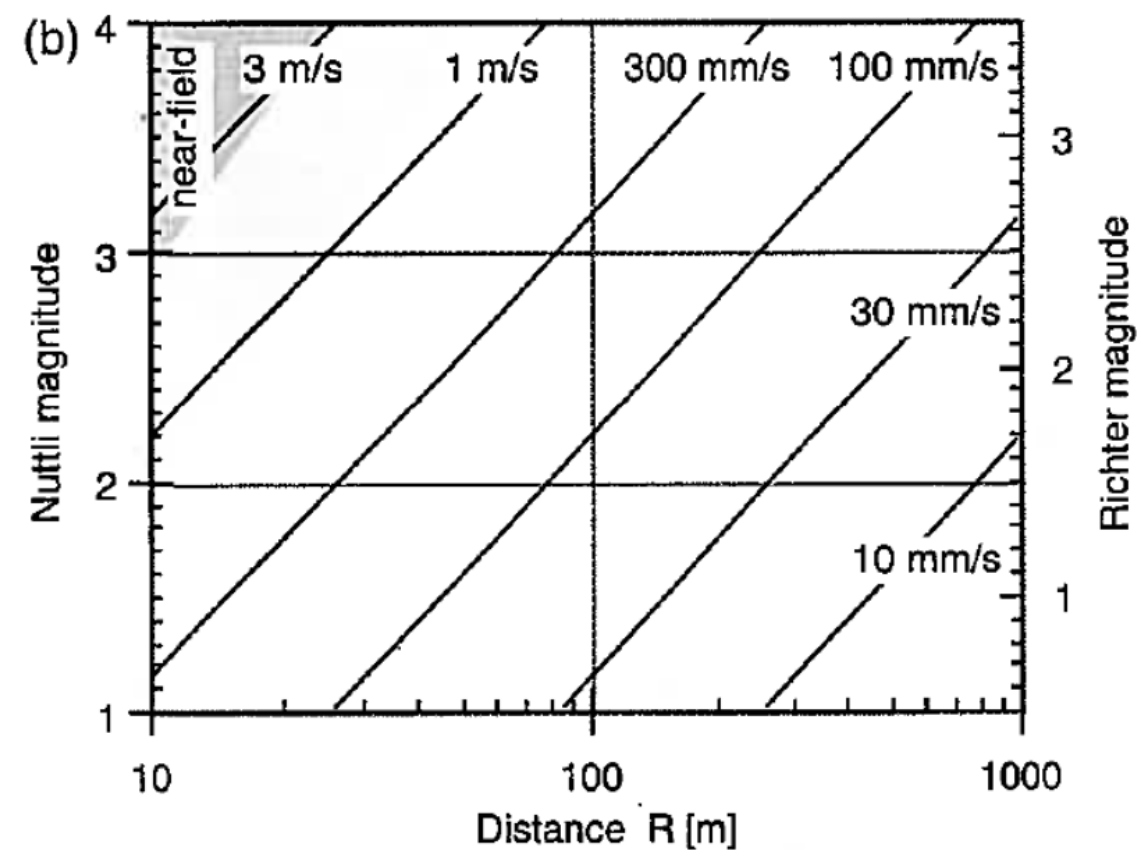

Figure 5 Peak particle velocity for recommended design conditions (90 to $95 \%$ confidence and normal stress drop; $\mathrm{a}^{*}=0.5$ and $\mathrm{c}^{*}=0.25 \mathrm{~m}^{2} / \mathrm{s}$ (reproduced from Kaiser et al., 1996)

The attractiveness of Figure 5 is its simplicity and facility with which one can estimate the far-field and near-field ppv based on magnitude and location of events, which are readily available from seismic monitoring systems. As no other simple alternative exists, this graph has gained relative popularity with mine practitioners and researchers in recent years.

This generic form of the equation used was based on previous work by McGarr et al. (1981):

$$
\log _{10}\left(R \cdot v_{\max }\right)=A \cdot M+\log _{10}(C)
$$

Where:

$V_{\max }=$ the peak particle velocity.

$\mathrm{R}=\quad$ distance to the source $(\mathrm{m})$.

$\mathrm{M} \quad=\quad$ the magnitude of the seismic event.

$A$ and $C=$ are mine specific scaling parameters.

The attenuation effect on ppv is in this case simplified by using two site specific empirical constants that require calibration. Kaiser et al. (1996) used 95\% confidence limit regression analysis on seismic data populations from Brunswick Mining, El Teniente mine, Creighton mine, together with data from McGarr (1984), to recommend using values of $a=0.5$ and $c=0.25$ if seismic data from the specific mine is not available for calibration. Kaiser et al. (1996) also specified that this should lead to conservative (high) estimates of ppv, since $95 \%$ of the data is 'below the regression line'.

Using the values for A and C proposed by Kaiser et al. (1996) in Equation 1, it can be re-written as Equation 2 (Heal, 2010).

$$
v_{\max }=\frac{C \cdot 10^{a\left(M_{R}+1.5\right)}}{R}=\frac{0.25 \cdot 10^{0.5\left(M_{R}+1.5\right)}}{R} \approx \frac{1.4 \cdot 10^{M_{R}+1.5}}{R}
$$


(Note that Kaiser's calibration was made based on the Nuttli magnitude scale $\left(M_{n}\right)$, and for Local Richter scale $\left(M_{R}\right)$ : the following equivalence is suggested: $\left.M_{n}=\left(M_{R}+1.5\right)\right)$.

These equations do not in any way account for differences in the ground motion in the near field. According to Aki and Richards (1980), the near-field physically extends to once or twice the source radius. Although a few models have been proposed to quantify the near-field ppv, they rely on several assumptions. Durheim et al. (2005) further developed the original work of McGarr (1991) and present the ground motion relationship in the following form:

$$
v_{\max }=\begin{array}{ll}
\frac{V_{s} \cdot \Delta \sigma}{G} & \text { for } R \leq r_{0} \\
\frac{V_{s} \cdot \Delta \sigma}{G} \cdot \frac{r_{0}}{R} & \text { for } R>r_{0}
\end{array}
$$

Where:

$\mathrm{V}_{\max }=$ the peak particle velocity.

$\mathrm{V}_{\mathrm{s}} \quad=\quad$ shear wave velocity.

$\Delta \sigma \quad=\quad$ static stress drop.

$\mathrm{G}=$ shear stiffness of rock mass.

$r_{0}=$ the near-field radius.

$\mathrm{R}=$ hypocentral distance.

This equation shows a saturation of the ground motion in the near-field. This near-field saturation has also been suggested by earthquake studies (Campbell, 1981). Wesseloo (2010) suggested a modification to the original far-field relationship suggested by (Kaiser et al., 1996) to incorporate this saturation in the nearfield and is represented in Equation 4 and in Figure 6.

$$
p p v=\frac{C \cdot 10^{\frac{1}{2}\left(m_{L}+1.5\right)}}{R+R_{0}}
$$

Where:

$$
\begin{aligned}
& C \quad=\quad 0.2-0.3 \text { is recommended for design purposes. } \\
& R=\text { the distance. } \\
& R_{o}=\quad \text { the source radius }\left(R_{0}\right) \text { estimated as (Kaiser et al., 1996). } \\
& \qquad R_{0}=\alpha \cdot 10^{\frac{1}{3}\left(m_{L}+1.5\right)}
\end{aligned}
$$

Where:

$\alpha=0.53-1.14$. 


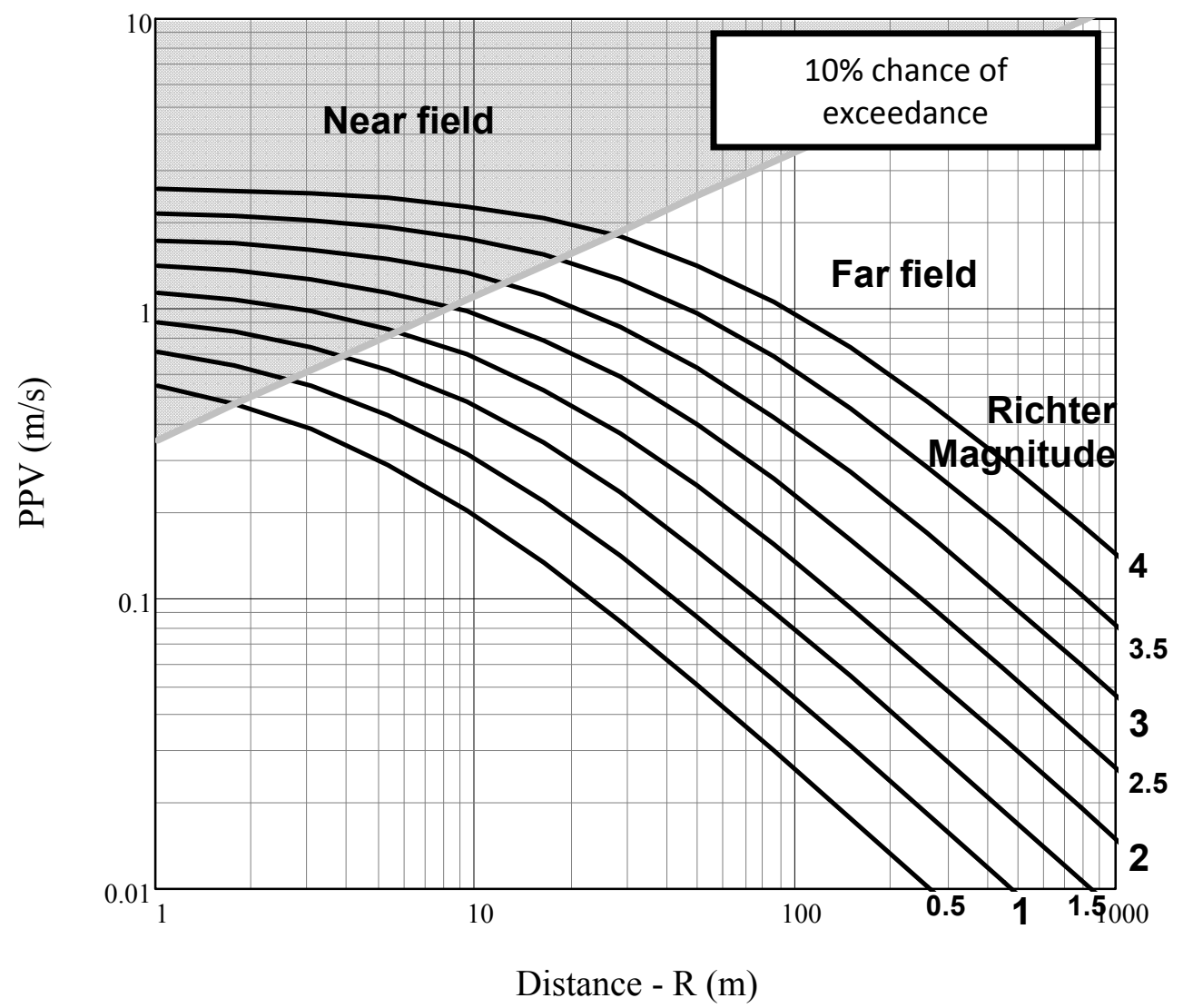

Figure 6 Graphical representation of the relationship between the magnitude-distance-ppv (after Wesseloo, 2010)

The near-field ppv is, however, complex, non-uniform and not well understood and investigation into this phenomenon is difficult due to the lack of reliable near-field data. As a result, these approaches to account for the near-field may be inadequate simplifications.

The same criticism may be applicable to the use of the general ground motion relationship and more reliable results may be achieved by deriving a site specific relationship based on data obtained from each site.

As mentioned before ppv is used as a design parameter to capture the severity of the influence of the seismic event at a distance. Unsurprisingly, the application of this type of oversimplified methodology often produces mixed results. Sometimes there appears to be a reasonable correlation between damage and estimated ppv but this is often not the case. Ignoring the effect of ground support, when back-analysing rockburst damage case studies using this simple graph, it is common to have low ppv values creating extensive damage to the rock mass and high ppv result in little or no damage. Morissette et al. (2012) plotted 133 cases of rockburst damage from the Creighton mine using a similar magnitude-distance-ppv graph (Figure 7). In this case, the generic ppv scaling attenuation law applied was the one proposed by Hedley (1992), which is similar to Equation 2 with different variable values, calibrated for Elliott Lake uranium mines. They concluded that based on this data, the relationship between the estimated ppv at the location of damage and the amount of damage appears to be random. They also made the important observation that:

"...the amount of displaced material from a rockburst depends on more variables than the magnitude and the distance". 


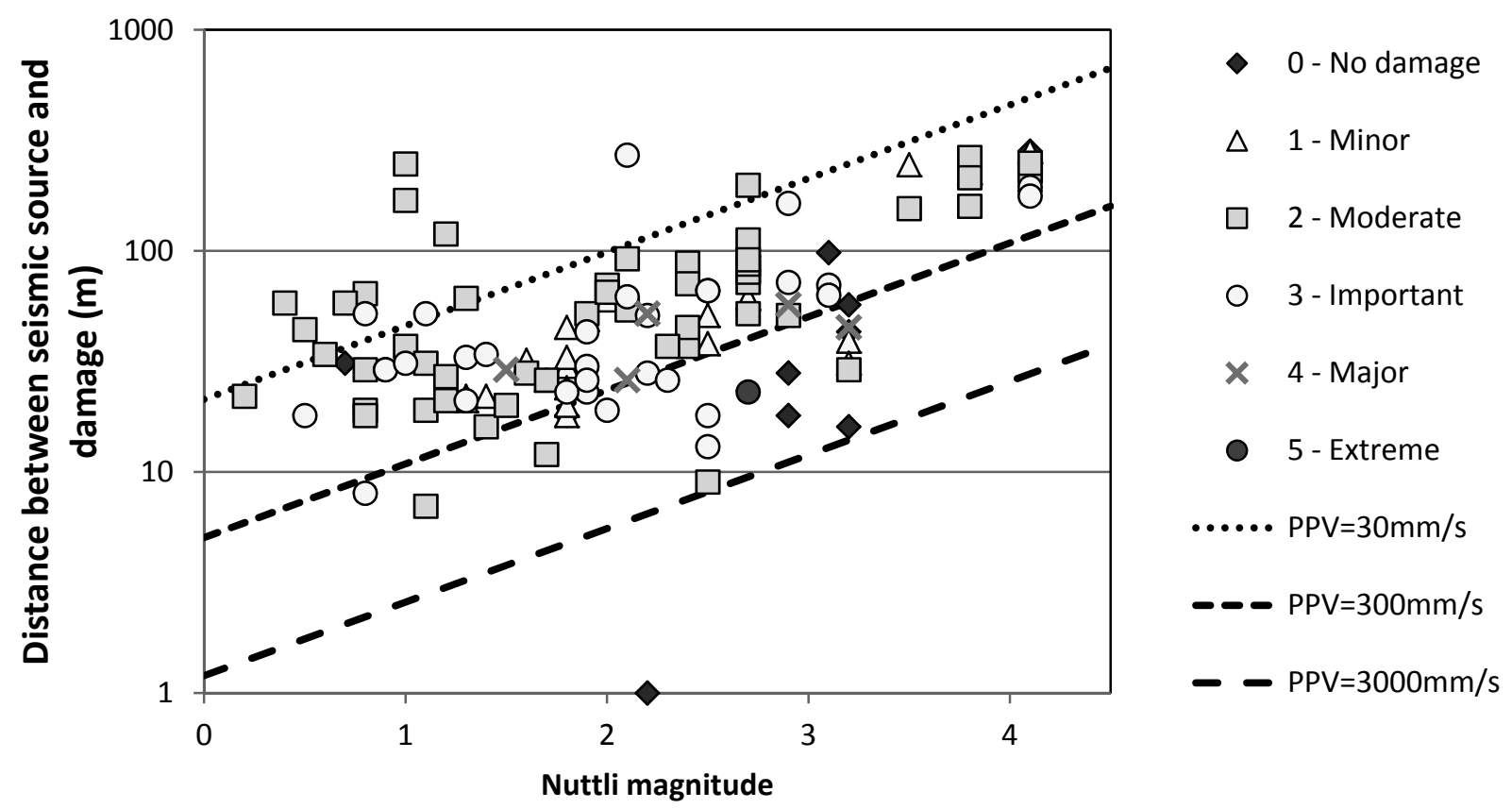

Figure 7 Magnitude-distance relation for rockbursts encountered at Creighton. Rockbursts are colour-coded based on rockburst damage index (reproduced from Morissette et al., 2012)

This highlights the fact that the complex nature of the problem cannot be reduced to a single design parameter. In this case, a design ppv, and any design methodology that is based on a theoretical ppv value without in any way accounting for the other factors influencing the excavation stability and support performance, will simply be inadequate.

Some of the effects that are likely contributing to the problem that needs to be accounted for are: the effect of the radiation pattern, the complexities in reflection and refraction, local site conditions and the effect of rock mass brittleness and the possibility of dynamic triggering of local brittle failure.

\subsection{The site effect}

From time to time, it has been observed that rock ejections following some rockbursts far exceeded the theoretical distance to which they should have travelled. Notwithstanding our poor understanding of factors such as anisotropy, reflection, refraction and attenuation (as discussed above), which can all have a strong influence on the seismic wave propagation and therefore the damage and ejection observed, it has been proposed that a site amplification effect can be responsible for the discrepancy between theoretical and observed ejection distances. The site effect is often described in anecdotal narratives from rockburst damage observations. Milev et al. (1999) estimate that the ppv can be amplified by four to ten times the expected value due to the site effect. Based on earlier work completed by Durrheim et al. (1998) and Hagan et al. (1999), Durrheim (2012) also suggested that the ground motion at the surface of excavations in South African mines can be amplified by a factor of four- to ten-fold. He also proposed, as a possible explanation for the site effect, that the amplitude of the stress waves can be expected to double at the surface of an excavation (Figure 8). This is not surprising given that the last layer of rock through which the wave travels before reaching the excavation is unconfined in at least one direction. It is reasonable to expect that the shape of the wave, i.e. a concave of convex curvature, will also influence the amount of amplification. 


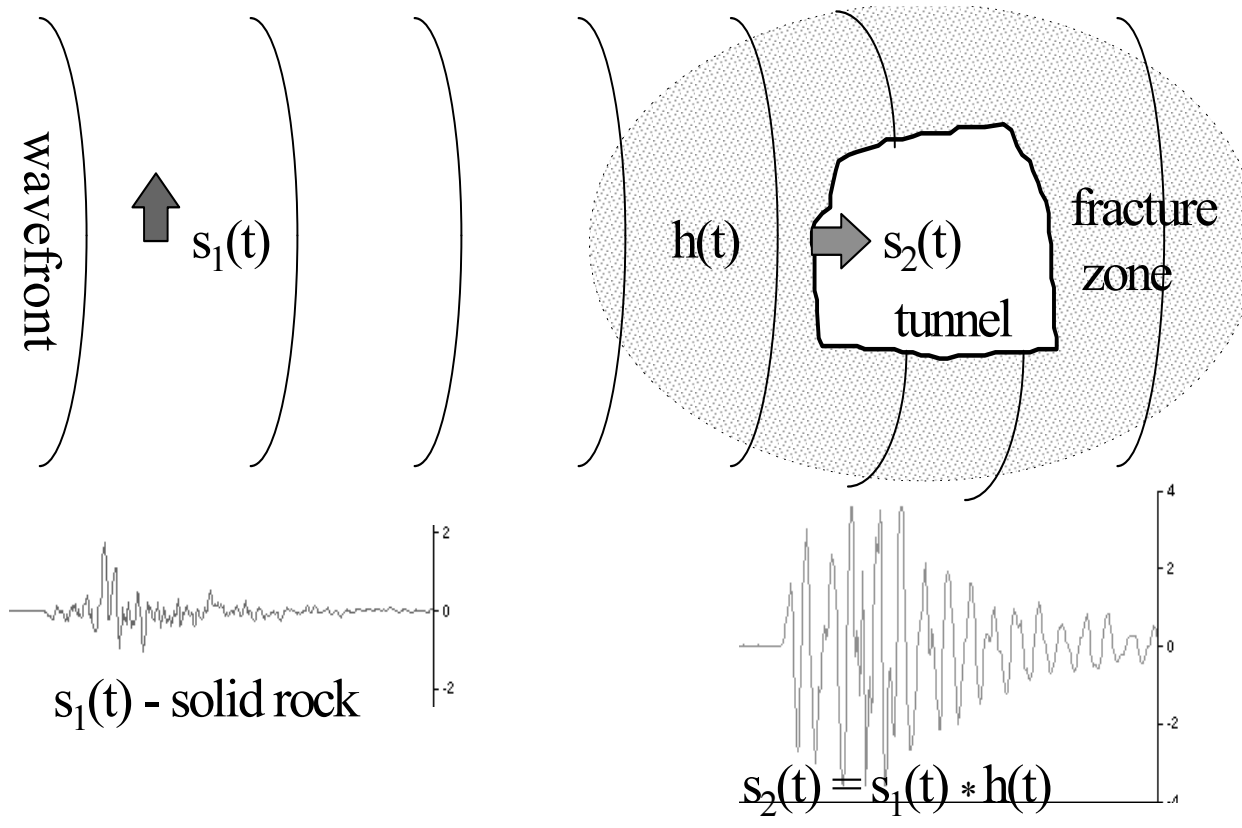

Figure 8 Diagram reproduced from Durrheim et al. (1996) showing the increase in the stress wave amplitude from seismograms recorded at $10 \mathrm{~m}$ from an underground drive (left) and at the surface of the drive (right)

Durrheim (2012) explained that the fractured zone typically present around excavations at depth creates a contrast in velocity which contributes to

"...trap seismic energy as the low velocity surface layer enhances the formation of surface waves such as Raleigh and Love waves."

The above proposition, combined with the possibility of wave superposition, emphasise the complexity of the stress wave interaction with excavations. Current design methodologies make an implicit assumption of a simple energy transfer akin to what happens in a 'Newton cradle' shown in Figure 9 while the reality is much more complex with repeated compression, shear, torsion, bending and pure tension loading in the walls of the excavation.

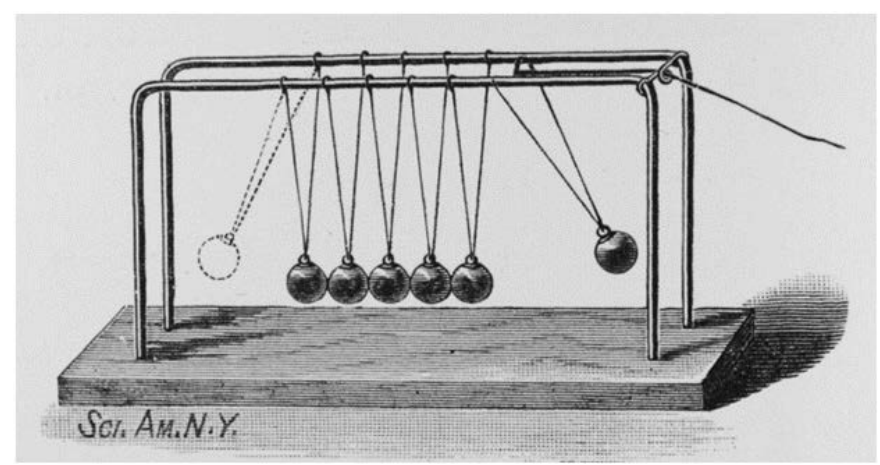

\section{Figure 9 Newton's Cradle}

Milev et al. (2002) have made a large number of ppv measurements at the surface of excavations at the TauTona mine, Kloof mine and Mponeng mine using a custom design surface-mounted instrument called the Peak Velocity Detector (PVD). 'Theoretical' ppv values calculated from the seismic monitoring systems projected at excavation locations were then compared to ppv values measured at the surface of excavations from the PVD instrument. If one assumes that the ratio between these two values is due to a site amplification factor, measurements indicated that this amplification varied between approximately one and 25 times the theoretical ppv, for each of the three mine sites, suggesting that the site effect may vary 
significantly, even within a mine. Webber (2000) correctly concludes that the site effect is highly variable from mine to mine and at this stage is poorly understood.

The quoted site factors of between one and 25 are likely to be the cumulative effect of different factors which include the radiation pattern, the complex interaction of the body waves with the geology and excavation, and the effect of surface waves. In order to improve the current approaches in support design, these effects need to be disentangled and quantified. The combined use of laboratory testing and numerical modelling may provide a valuable avenue to achieve this.

\subsection{The effect of rock brittleness}

Beyond the difficulties in understanding and modelling the stress wave attenuation and propagation phenomena and accounting for the amplification of ppv due to the site effect, it is proposed that rock brittleness around excavations can also play a major role in the rockburst damage outcome.

Let us consider a certain volume of brittle rock located close to an excavation and submitted to a high stress regime. If loading of the volume of rock approaches its peak strength value, then it is conceivable that even a relatively small and/or attenuated stress wave from a far field event may be sufficient to bring the rock mass beyond peak strength, and trigger a self-sustained violent failure near the excavation. This concept is similar to the idea of dynamic remote triggering of earthquake aftershock (Kijko and Funk, 1996; Naoi, 2011; Butt et al., 1998) which Kgarume (2010) suggests may be applicable to mining.

This may provide an additional explanation to the amplification of the ppv due to the site effect where extensive damage is observed as a result of low 'calculated' ppv from either a small event or a large but distant event (like the yellow and red points with ppv lower than $300 \mathrm{~mm} / \mathrm{s}$ in Figure 107).

The work of Tarasov (Tarasov, 2010, 2011; Tarasov and Randolph, 2011; Tarasov and Potvin, 2012) provided evidence that for brittle rock under triaxial compression, a significant portion of the stored elastic strain energy is not consumed during the fracturing process. The unconsumed energy or the 'released energy' can then be transformed into the failure process dynamics, particularly associated with fragmentation, flying fragments, seismicity, heat, etc.

Figure 10 shows generic stress-strain curves of ductile rock classified as Class 1 and brittle rock classified as Class 2 based on Wawersik and Fairhurst (1970) classification. The energy balance at three different stages of deformation is shown using the coloured polygons. The first graph on the left is at peak stress (point B), the middle graph is at an intermediate post-peak stage, and the right graph is at failure (point C). The red triangles represent the elastic energy stored in the rock specimen whilst the grey area is the energy consumed during post rupture. The yellow area represents the excess energy and occurs only for brittle rock Class 2. 

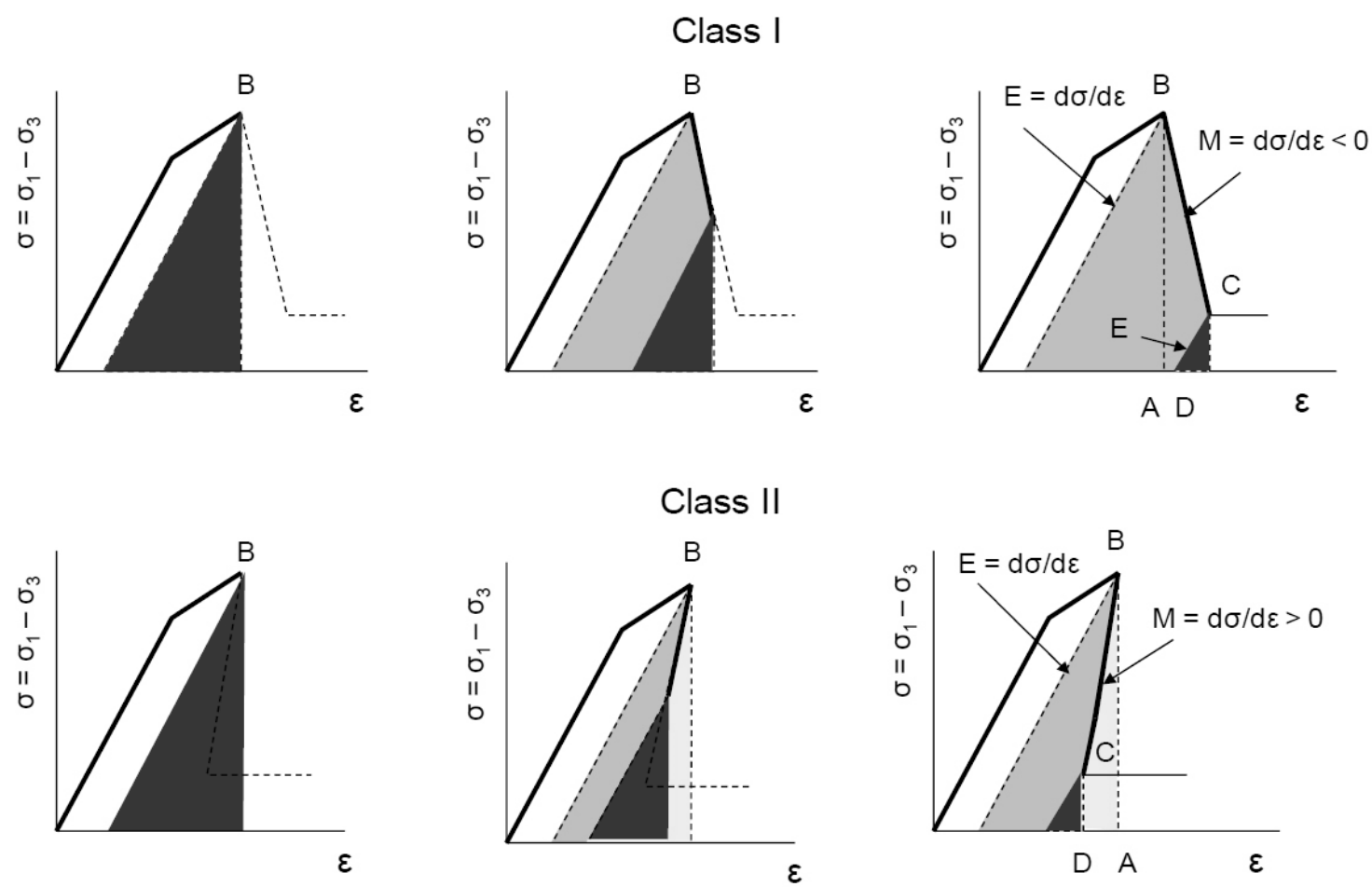

Figure 10 Illustration of the post-peak energy balance for rocks of Class I and Class II behaviour (reproduced from Tarasov and Potvin, 2012)

Tarasov and Potvin (2012) described the energy transformation as follows:

"The graphs illustrate the dynamics of transforming the elastic energy accumulated within the specimen material at peak stress, into post-peak rupture energy. The red areas (elastic energy) are partly replaced in the graphs by the grey areas (rupture energy). The elastic energy represents the source of the post-peak failure process and provides the physical basis for the post-peak failure regime. For Class II, the fracture development occurs entirely due to the elastic energy available from the material. The failure process has a self-sustaining character, with the release of excess energy, corresponding to the yellow area $(A B C D)$."

Clearly, the above laboratory results show that brittle rock (Class 2 ) under triaxial compression and loaded at near post-peak stress (possibly located at a short distance from the excavation) is clearly capable of releasing a significant amount of energy during the post-peak failure process, even if the trigger is a modest stress wave from a far-field event. Therefore, adding to the possible site amplification effect and the possible superposition of stress waves, the strain elastic energy my also contribute to larger than expect ppv and damage.

\section{$4 \quad$ Seismic events and rockburst damage mechanisms and the demand on ground support}

A number of authors have proposed mechanisms for mine induced seismic events (Gibowicz, 1990; Hasegawa et al., 1989; Ortlepp, 1997; Hudyma, 2009). In particular Gibowicz (1990) offer a very simple distinction between two types of seismic events:

1. "Those directly connected with mining operations, i.e. those associated with the formation of fractures at stope faces.

2. Those that are not, i.e. those associated with movement on major geological discontinuities".

By definition, the damage associated with type one mechanism would generally be associated with the event's near-field ppv and the issues identified earlier relating to propagation and attenuation and, to a lesser extent, anisotropy and even perhaps the site amplification effect would not have a major influence 
on the demand on ground support. On the other hand, the stored elastic energy and more specifically the release of excess energy associated with brittle rock will most likely be a dominating factor in estimating the demand on ground support.

One can correlate the Gibowicz (1990) type one mechanism with the first three mechanisms (strain-burst, buckling and face/pillar burst) proposed by Ortlepp (1997) shown in Table 1. All three are closely associated with an excavation, are believed to be dominantly implosive motion and are on the lower end of the magnitude scale. These mechanisms require a free surface to occur and thus occur at a lower confining stress. The violence of such a burst is expected to increase with lower confining stress.

Also by definition, the damage associated with the Gibowicz type two mechanism would generally be associated with, or at least triggered by the far-field ppv. This makes the assessment of the demand on ground support more complicated as it is affected by all the factors described in the previous sections of this paper, including propagation/attenuation, site effect and brittleness. The type two mechanism can be correlated with the last two mechanisms (shear rupture and fault-slip) of Ortlepp's Table 1. Although they could be associated with excavations, they are often located remote from them in areas where confinement is significant, the motion is predominantly shear and they account for the higher end of mine induced seismic event magnitudes. They are also often responsible for major damage either by inducing sufficiently strong ground motion to overcome the capacity of the support or by triggering a type one event at the boundary of the excavation.

Table 1 Classification of seismic event mechanisms modified after Ortlepp (1997)

\begin{tabular}{|c|c|c|c|c|}
\hline $\begin{array}{l}\text { Confining } \\
\text { Stress }\end{array}$ & $\begin{array}{l}\text { Seismic } \\
\text { Event }\end{array}$ & Postulated Source Mechanism & $\begin{array}{l}\text { First Motion from } \\
\text { Seismic Records }\end{array}$ & $\begin{array}{c}\text { Richter } \\
\text { Magnitude } \\
\text { M }_{\mathrm{L}}\end{array}$ \\
\hline \multirow{5}{*}{$\begin{array}{l}\text { Increasing } \\
\text { confining } \\
\text { stress }\end{array}$} & Strain-burst & $\begin{array}{l}\text { Superficial spalling with violent } \\
\text { ejection of fragments }\end{array}$ & $\begin{array}{l}\text { Usually undetected, } \\
\text { could be implosive }\end{array}$ & $-0.2-0$ \\
\hline & Buckling & $\begin{array}{l}\text { Outward explosion of large } \\
\text { slabs pre-existing parallel to } \\
\text { surface of opening }\end{array}$ & Implosive & $0-1.5$ \\
\hline & $\begin{array}{l}\text { Face crush / } \\
\text { pillar burst }\end{array}$ & $\begin{array}{l}\text { Violent explosion of rock from } \\
\text { stope face or pillar sides }\end{array}$ & $\begin{array}{l}\text { Mostly implosive, } \\
\text { complex }\end{array}$ & $1.0-2.5$ \\
\hline & $\begin{array}{l}\text { Shear } \\
\text { rupture }\end{array}$ & $\begin{array}{l}\text { Violent propagation of shear } \\
\text { fracture through intact rock } \\
\text { mass }\end{array}$ & Double-couple shear & $2.0-3.52$ \\
\hline & Fault-slip & $\begin{array}{l}\text { Violent renewed movement on } \\
\text { existing fault or dyke contact }\end{array}$ & Double-couple shear & $2.5-5.0$ \\
\hline
\end{tabular}

Regardless of the seismic event mechanism, or the origin and nature of the ground motion, or whether the damage is caused by near-field or far-field ppv, the damage according to Kaiser et al. (1996) can be expressed as three distinct processes: rock fracturing, displacement and ejection. The rock fracturing occurs when the peak strength of a volume of rock is exceeded due to either the incoming stress wave (Gibowicz Type 2 seismic event mechanism) or by sudden or gradual stress change due to a change in geometry after blasting (Gibowicz Type 1 seismic event mechanism). In both cases, the energy input in the system is from a transient stress wave of the seismic event itself or from the seismic event combined with the elastic strain energy (for brittle rock). These two potential sources of energy will be dissipated as rock fracturing, and the unconsumed energy will be released in rock mass displacement (or bulking) and ejection. The last two (bulking and ejection) will likely be transferred to the ground support system.

Figure 11 illustrates how the support system is being loaded. The rock fracturing and bulking will contribute to stretching of the surface support (shotcrete or mesh) to a displacement $D$. The displacement of the 
reinforcement $d$ will be the result of the surface movement transferring tensile load to the bolt together with the internal bulking of the rock mass which also produces an axial load on the bolts. The support system will be stable if the portion of the energy from the seismic event combined with the stored strain elastic energy (in the case of brittle rock) unused during the fracturing process can be dissipated by the ground support system deformation. The ground support system capacity to dissipate this energy can be very low, if one component of the system is weak (often referred to as the weakest link) (Simser, 2007).

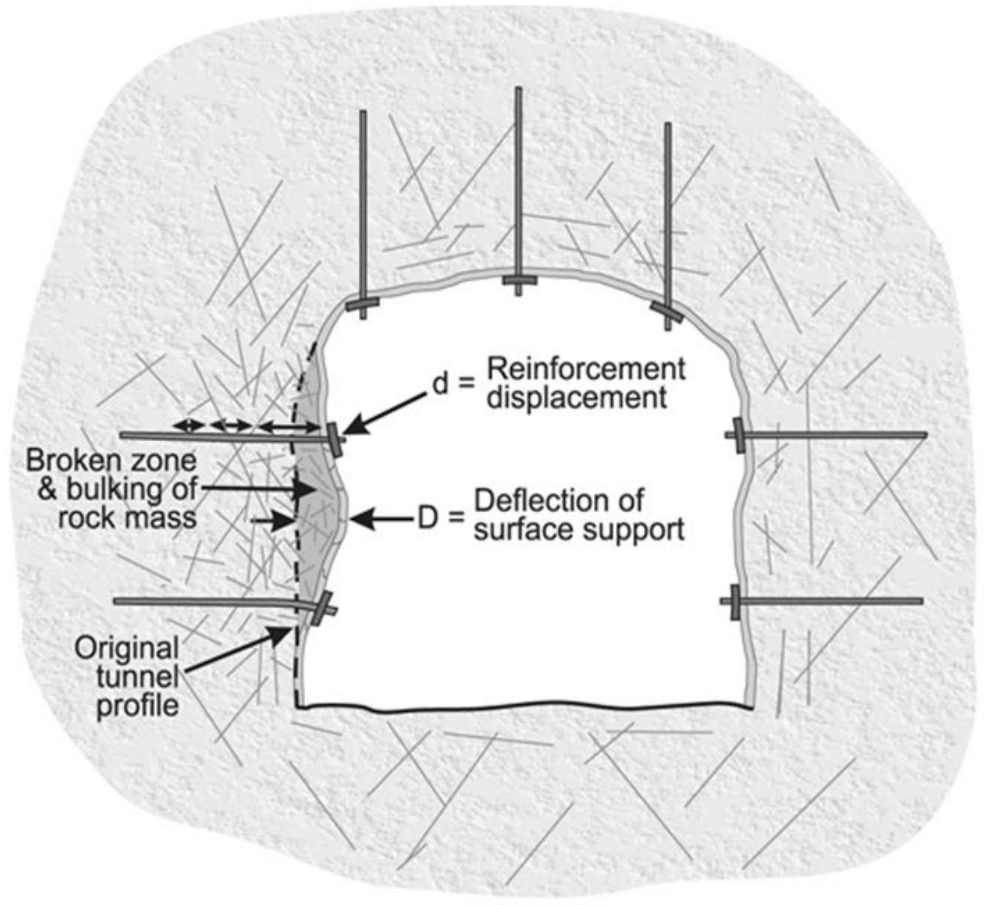

Figure 11 Illustration of the support system deformation as a result of rock fracturing and bulking (after Potvin et al., 2010)

\section{$5 \quad$ Conclusion}

In this paper we examined some of the complexities in dynamic support design and the inadequacies of current approaches. The current state of knowledge does not allow determination with any confidence of the capacity or the demand of ground support systems under dynamic loading. Therefore, this is an indeterminate problem. Peak ground motion (or ppv) has been favoured to date to characterise the dynamic demand but the ppv as a design parameter is insufficient to adequately capture the complexity of the problem.

If the seismic event is further away from an excavation, the radiation pattern and the complex interaction between the seismic waves, geology and mining excavations must be accounted for. The local site effect and the phenomenon of triggering of local strain-burst or buckling type events in stressed brittle rock also needs to be further investigated.

The contribution from each of these mechanisms must be quantified to determine the dynamic demand on ground support.

\section{Acknowledgement}

The ACG sincerely thanks the following organisations who provided funding for this research through the Mine Seismicity and Rockburst Risk Management project: Barrick Gold of Australia, BHP Billiton Nickel West, BHP Billiton Olympic Dam, Independence Group (Lightning Nickel), LKAB, Perilya Limited (Broken Hill Mine), Vale Inc., Agnico-Eagle Canada, Gold Fields St Ives Gold Operations, Hecla USA, Kirkland Lake Gold, 
MMG Golden Grove, Newcrest Cadia Valley Operations, Newmont Asia Pacific, Xstrata Copper (Kidd Mine), Xstrata Nickel Rim, and The Minerals and Energy Research Institute of Western Australia.

\section{References}

Aki, K. and Richards, P.G. (1980) Quantitative seismology theory and methods, W.H. Freeman and Company, San Francisco, California, $932 \mathrm{p}$.

Andrieux, P., Turichshev, A., O'Connor, P. and Brummer, R.K. (2005) Dynamic testing with explosive charges of rockburst-resistant ground support systems at the Fraser Nickel Mine, Itasca Consulting Canada Inc., Report to Falconbridge Limited Mine Technical Services; Final Version, September 2005, Sudbury, Canada.

Archibald, J.F., Baidoe, J.P. and Katsabanis, P.T. (2003) Rockburst damage mitigation benefits deriving from use of spray-on rock linings, in Proceedings Third International Seminar on Surface Support Liners: Thin Spray-on Liners, Shotcrete and Mesh, 25-27 August 2003, Quebec City, Canada, Section 19.

Butt, S.D., Calder, P.N. and Apel, D.B. (1998) The use of high frequency and mine-wide microseismic systems to monitor the movement of blasting induced stresses, CIM bulletin, Vol. 93, No. 1040, pp. 90-95.

Campbell, K.W. (1981) Near-source attenuation of peak horizontal attenuation, Bulletin of the Seismology Society of America, Vol. 71, No. 6, pp. 2039-2070.

Daehnke, A. (1997) Stress wave and fracture propagation in rock, PhD Thesis, Technical University of Vienna, October 1997.

Durrheim, R.J. (2012) Functional specifications for in-stope support based on seismic and rockburst observations in South African mines, in Proceedings Sixth International Seminar on Deep and High Stress Mining (Deep Mining 2012), Y. Potvin (ed), 28-30 March 2012, Perth, Australia, Australian Centre for Geomechanics, Perth, pp. 41-55.

Durrheim, R., Spottiswoode, S., Roberts, M. and van Brink, A.Z. (2005) Comparative seismology of the Witwatersrand Basin and Bushveld Complex and emerging technologies to manage the risk of rockbursting, Journal of the South African Institute of Mining and Metallurgy, Vol. 105, pp. 409-416, http://www.saimm.co.za/Journal/v105n06p409.pdf.

Durrheim, R.J., Milev, A., Spottiswoode, S.M. and Vakalisa, B. (1998) Improvement of worker safety through the investigation of the site response to rockbursts, Final report GAP201 (unpublished), Mine Health and Safety Council, Johannesburg.

Durrheim, R.J., Kullmann, D.H., Stewart, R.D. and Chichowicz, A., (1996) Seismic excitation of the rock mass surrounding an excavation in highly stressed ground, in Proceedings 2nd North American Rock Mechanics Symposium, M. Aubertin, F. Hassani and H. Mitri (eds), pp. 389-394.

Espley, S.J., Heilig, J. and Moreau, L.H. (2002) Assessment of the dynamic capacity of liners for application in highly-stressed mining environments at Inco Limited, in Proceedings International Seminar on Surface Support Liners, 29-31 July 2002, Johannesburg, South Africa.

Gaudreau, D., Aubertin, M. and Simon, R. (2004) Performance of tendon support systems submitted to dynamic loading, in Proceedings Fifth International Symposium on Ground Support, Ground Support in Mining and Underground Construction, E. Villaescusa and Y. Potvin (eds), 28-30 September 2004, Perth, Australia, Balkema, Rotterdam, pp. 299-312.

Gibowicz, S.J. (1990) The mechanism of seismic events induced by mining: A review, in Proceedings Rockbursts and Seismicity in Mines, C. Fairhurst (ed), 16-18 August 1993, Minneapolis, USA, Balkema, Rotterdam, pp. 3-27.

Hagan, T.O., Milev, A.M., Spottiswoode, S.M., Hildyard, M.W., Grodner, M., Rorke, A.J., Finnie, G.J., Reddy, N., Haile, A.T., Le Bron, K.B. and Grave, D.M. (2001) Simulated rockburst experiment - an overview, The Journal of The South African Institute of Mining and Metallurgy, August 2001, pp. 217-222.

Hagan, T.O., Milev, A.M., Spottiswoode, S.M., Vakalisa, B. and Reddy, N. (1999) Improvement of worker safety through the investigation of the site response to rockbursts (Continuation of GAP 201), Final report GAP530 (unpublished), Mine Health and Safety Council, Johannesburg.

Hasegawa, H.S., Wetmiller, R.J. and Gendzwill, D.J. (1989) Induced seismicity in mines in Canada - an overview, Pure and Applied Geophysics, Birkhäuser-Verlag, Vol. 129, Issue 3-4, pp. 423-453.

Heal, D. (2010) Observations and analysis of incidences of rockburst damage in underground mines, School of Civil and Resource Engineering, The University of Western Australia, Perth, Australia, PhD thesis, $357 \mathrm{p}$.

Heal, D. and Potvin, Y. (2007) In-situ dynamic testing of ground support using simulated rockbursts, in Proceedings Fourth International Seminar on Deep and High Stress Mining (Deep Mining 07), Y. Potvin (ed), 7-9 November 2007, Perth, Australia, Australian Centre for Geomechanics, Perth, pp. 373-394.

Heal, D., Hudyma, M., Langille, C., Potvin, Y., Butcher, R., Ball, R. and Hartmann, B. (2005) In-situ testing of ground support performance under strong dynamic loading, in Proceedings Sixth International Symposium on Rockburst and Seismicity in Mines (RaSiM6), Y. Potvin and M. Hudyma (eds), 9-11 March 2005, Perth, Australia, Australian Centre for Geomechanics, Perth, pp. 85-94.

Hedley, D.G.F. (1992) Rockburst handbook for Ontario hardrock mines, CANMET, Energy, Mines and Resources Canada, Special Report SP92-1E.

Hudyma, M.R. (2009) Analysis and interpretation of clusters of seismic events in mines, The University of Western Australia, Perth, Australia, PhD thesis.

Hildyard, M. (2007) Manuel Rocha Medal Recipient, Wave interaction with underground openings in fractured rock, Rock Mechanics and Rock Engineering, Vol. 40 (6), pp. 531-561.

Hildyard, M.W. and Milev, A.M. (2001) Simulated rockburst experiment: Numerical back-analysis of seismic wave interaction with the tunnel, The Journal of The South African Institute of Mining and Metallurgy, August 2001, pp. 223-234. 
Kaiser, P. and Maloney, S. (1997) Scaling Laws for the Design of Rock Support, Pure and Applied Geophysics, Vol. 150, Issue 3-4, pp. 415-434.

Kaiser, P.K., McCreath, D.R. and Tannant, D.D. (1996) Canadian Rockburst Support Handbook, Canadian Rockburst Research Program 1990-1995, Camiro.

Kgarume, T. (2010) Mine Aftershocks and Implications for Seismic Hazard Assessment, University of the Witwatersrand, Johannesburg, South Africa, Masters thesis.

Kijko, A. and Funk, C.W. (1996) Space-time interaction amongst clusters of mining induced seismicity, Pure and Applied Geophysics, Vol. 147, No. 2, pp. 277-288.

McGarr, A. (1991) Observations constraining near-source ground motion estimated from locally recorded seismograms, Journal of Geophysical Research, Vol. 96, No. B10, pp. 16495-16508.

McGarr, A., Green, R.W. and Spottiswoode, S.M. (1981) Strong ground motion of mine tremors: some implications for near-source ground motion parameters, Bulletin of the Seismological Society of America, No. 71, pp. 295-319.

McGarr, A. (1983) Estimated ground motion for small near-by earthquakes, Seismic Design of Embankment and Caverns, New York, American Society of Civil Engineers, pp. 113-127.

McGarr, A. (1984) Scaling of ground motion parameters, state of stress, and focal depth, Journal of Geophysical Research, Vol. 89, pp. 6969-6979.

Milev, A.M., Spottiswoode, S.M., Noble, B.R., Linzer, L.M., van Zyl, M., Daehnke, A. and Acheampong, E. (2002) The meaningful use of peak particle velocities at excavation surfaces for the optimisation of the rockburst criteria for tunnels and stopes, SIMRAC GAP Project 709 - Final Report.

Milev, A.M., Spottiswoode, S.M. and Stewart, R.D. (1999) Dynamic response of the rock surrounding deep level mining excavations, in Proceedings 9th International Congress on Rock Mechanics, 25-28 August 1999, Paris, France, pp. 1109-1114.

Morissette, P., Hadjigeorgiou, J. and Thibodeau, D. (2012) Validating a support performance database based on passive monitoring data, in Proceedings Sixth International Seminar on Deep and High Stress Mining (Deep Mining 2012), Y. Potvin (ed), 28-30 March 2012, Perth, Australia, Australian Centre for Geomechanics, Perth, pp. 41-55.

Naoi, M. (2011) Twenty Thousand Aftershocks of a Very Small (M 2) Earthquake and Their Relation to the Mainshock Rupture and Geological Structures, Bulletin of the Seismological Society of America, Vol. 101, No. 5, pp. 2399-2407.

Newmark, N.M. and Hall, W.J. (1982) Earthquake spectra and design, EERI Monograph Series, Earthquake Engineering Research Institute, Berkeley, CA.

Ortlepp, W.D. and Swart, A.H. (2002) Extended use of the Savuka dynamic test facility to improve material and analytical technology in deep-level stope support, SIMRAC Report GAP 818.

Ortlepp, W.D., Stacey, T.R. and Kirsten, H.A.D. (1999) Containment support for large static and dynamic deformations in mines, in Proceedings of the International Symposium on Ground Support, E. Villaescusa, C.R. Windsor and A.G. Thompson (eds), 15-17 March 1999, Kalgoorlie, Western Australia, Balkema, Rotterdam, pp. 389-364.

Ortlepp, W.D. and Stacey, T.R. (1998) Testing of tunnel support: dynamic load testing of rockbolt elements to provide data for safer support design, SIMRAC GAP Project 423.

Ortlepp, W.D. (1997) Rock fracture and rockbursts, Monograph Series M9, South African Institute of Mining and Metallurgy, Johannesburg, South Africa.

Ortlepp, W.D. and Stacey, T.R. (1997) Testing of tunnel support: dynamic load testing of rock support containment systems, SIMRAC GAP Project 221.

Player, J., Villaescusa, E. and Thompson, A.G. (2009) Dynamic testing of friction rock stabilisers, Paper 4027 - Rock Engineering in Difficult Conditions, in Proceedings 3rd Canada-US Rock Mechanics Symposium and 20th Canadian Rock Mechanics Symposium, 9-15 May 2009, Toronto, Canada.

Player, J.R., Thompson, A.G. and Villaescusa, E. (2008a) Dynamic testing of reinforcement system, in Proceedings Sixth International Symposium on Ground Support in Mining and Civil Engineering Construction, T.R. Stacey and D. Malan (eds), SAIMM Symposium Series S51, 30 March - 4 April 2008, Cape Town, South Africa, pp. 581-595.

Player, J.R., Morton, E.C., Thompson, A.G. and Villaescusa, E. (2008b) Static and dynamic testing of steel wire mesh for mining applications of rock surface support, in Proceedings Sixth International Symposium on Ground Support in Mining and Civil Engineering Construction, T.R. Stacey and D. Malan (eds), SAIMM Symposium Series S51, 30 March - 4 April 2008, Cape Town, South Africa, pp. 693-706.

Player, J.R., Villaescusa, E. and Thompson, A.G. (2004) Dynamic testing of rock reinforcement using the momentum transfer concept, in Proceedings Fifth International Symposium on Ground Support in Mining and Underground Construction, E. Villaescusa and Y. Potvin (eds), 28-30 September 2004, Perth, Australia, Balkema, Rotterdam, pp. 327-340.

Plouffe, M., Anderson, T. and Judge, K. (2008) Rock bolts testing under dynamic conditions at CANMET-MMSL, in Proceedings Sixth International Symposium on Ground Support in Mining and Civil Engineering Construction, T.R. Stacey and D. Malan (eds), SAIMM Symposium Series S51, 30 March - 4 April 2008, Cape Town, South Africa, pp. 581-595.

Potvin, Y., Wesseloo, J. and Heal, D. (2010) An interpretation of ground support capacity submitted to dynamic loading, in Proceedings Fifth International Seminar on Deep and High Stress Mining (Deep Mining 2010), M. Van Sint Jan and Y. Potvin (eds), 6-8 October 2010, Santiago, Chile, Australian Centre for Geomechanics, Perth, pp. 251-272. Also in Mining Technology. 119 (4), 1-13. DOI10.1179/037178410X12886993781746.

Potvin, Y. (2009) Strategies and Tactics to Control Seismic Risks in Mines, Journal of the Southern African Institute of Mining and Metallurgy, Vol. 109, March 2009, pp. 177-186.

Reddy, N. and Spottiswoode, S.M. (2001) The influence of geology on a simulated rockburst, Journal of the South African Institute of Mining and Metallurgy, August 2001, pp. 267-272. 
Stacey, T.R. (2012) Philosophical view on the testing of rock support for rockburst conditions, in Proceedings Second Southern Hemisphere International Rock Mechanics Symposium (SHIRMS 2012), Symposium Series S71, 15-17 May 2012, Sun City, South Africa, pp. 227-247.

Stacey, T.R. and Ortlepp, W.D. (1999) Retainment support for dynamic events in mining, Rock Support and Reinforcement Practice in Mining, pp. 329-333.

Simser, B.P. (2007) The weakest link - Ground support observations at some Canadian Shield hard rock mines, in Proceedings Fourth International Seminar on Deep and High Stress Mining (Deep Mining 07), Y. Potvin (ed), 7-9 November 2007, Perth, Australia, Australian Centre for Geomechanics, Perth, pp. 335-348.

St John, C. and Zahrah, T. (1987) Aseismic design of underground structures, Tunnelling and Underground Space Technology, Vol. 2(2), pp. 165-197.

Tannant, D.D., McDowell, G.M. and McCreath, D.R. (1994) Shotcrete performance during simulated rockbursts, in Proceedings International Workshop on Applied Rockburst Research, 12 May 1994, Santiago, Chile.

Tannant, D.D, McDowell, G.M., Brummer, R.K. and Kaiser, P.K. (1993) Ejection velocities measured during a rockburst simulation experiment, in Proceedings International Symposium on Rockbursts and Seismicity in Mines, 16-18 August, Kingston, Canada, pp. 129-133.

Tarasov, B. and Potvin, Y. (2012) Absolute, relative and Intrinsic rock Brittleness at compression, in Proceedings Sixth International Seminar on Deep and High Stress Mining (Deep Mining 2012), Y. Potvin (ed), 28-30 March 2012, Perth, Australia, Australian Centre for Geomechanics, Perth, pp. 313-324.

Tarasov, B.G. (2011) Universal scale of brittleness for rocks failed at compression, in Proceedings 13th International Conference of the International Association for Computer Methods and Advances in Geomechanics (IACMAG 13), 9-11 May 2011, Melbourne, Australia, pp. 669-673.

Tarasov, B.G., Randolph, M.F. (2011) Superbrittleness of rocks and earthquake activity, International Journal of Rock Mechanics and Mining Sciences, Vol. 48, pp. 888-898.

Tarasov, B.G. (2010) Superbrittleness of rocks at high confining pressure, in Proceedings Fifth International Seminar on Deep and High Stress Mining (Deep Mining 2010), M. Van Sint Jan and Y. Potvin (eds), 6-8 October 2010, Santiago, Chile, Australian Centre for Geomechanics, Perth, pp. 119-133.

Villaescusa, E., Thompson, A.G. and Player, J. (2005) Dynamic testing of rock reinforcement systems, in Proceedings CRCMining Australian Mining Technology Conference - New Technologies to Produce More with Less, H. Gurgenci, M. Hood, P. Lever and P. Knights (eds), Western Australia, 26-28 September, Fremantle, Australia, The AusIMM, Melbourne, pp. 79-95.

Wawersik, W.R. and Fairhurst, C. (1970) A study of brittle rock fracture in laboratory compression experiments, International Journal of Rock Mechanics and Mining Sciences, 1970, Vol. 7, pp. 561-575.

Webber, S.J. (2000) Analysis of Seismic Data from a Hard Rock Western Australian Mine: Implications for Support Design, Snowden technical report, unpublished.

Wesseloo, J. (2010) Unpublished notes, Australian Centre for Geomechanics.

$\mathrm{Yi}, \mathrm{X}$. and Kaiser, P.K. (1994) Impact testing for rockbolt design in rockburst conditions, International Journal of Rock Mechanics and Geomechanics Abstracts, Vol. 31, No. 6, pp. 67-68. 